\title{
Is the profitability of Canadian freestall farms associated with their performance on an animal welfare assessment?
}

\author{
M. Villettaz Robichaud,*1 J. Rushen,† A. M. de Passillé,† E. Vasseur,ł D. Haley,§ K. Orsel,\# and D. Pellerin* \\ *Department of Animal Science, Université Laval, Québec, Québec, Canada, G1V 0A6 \\ †UBC Dairy Education and Research Centre, University of British Columbia, Agassiz, British Columbia, Canada, V0M 1A2 \\ ‡Department of Animal Science, McGill University, Sainte-Anne-de-Bellevue, Québec, Canada, H9X 3V9 \\ §Department of Population Medicine, Ontario Veterinary College, University of Guelph, Guelph, Ontario, Canada, N1G 2W1 \\ \#Department of Production Animal Health, University of Calgary, Calgary, Alberta, Canada, T2N 4N1
}

\begin{abstract}
Improving animal welfare on farm can sometimes require substantial financial investments. The Canadian dairy industry recently updated their Code of Practice for the care of dairy animals and created a mandatory on-farm animal care assessment (proAction Animal Care). Motivating dairy farmers to follow the recommendations of the Code of Practice and successfully meet the targets of the on-farm assessment can be enhanced by financial gain associated with improved animal welfare. The aim of the current study was to evaluate the association between meeting or not meeting several criteria from an on-farm animal welfare assessment and the farms' productivity and profitability indicators. Data from 130 freestall farms (20 using automatic milking systems) were used to calculate the results of the animal care assessment. Productivity and profitability indicators, including milk production, somatic cell count, reproduction, and longevity, were retrieved from the regional dairy herd improvement association databases. Economic margins over replacement costs were also calculated. Univariable and multivariable linear regression models were used to evaluate the associations between welfare and productivity and profitability indicators. The proportion of automatic milking system farms that met the proAction criterion for hock lesions was higher compared with parlor farms and lower for the neck lesion criterion. The proAction criterion for lameness prevalence was significantly associated with average corrected milk production per year. Average days in milk (DIM) at first breeding acted as an effect modifier for this association, resulting in a steeper increase of milk production in farms that met the criterion with increasing average DIM at first breeding. The reproduction and longevity in-
\end{abstract}

Received June 11, 2017.

Accepted November 3, 2017.

${ }^{1}$ Corresponding author: marianne.villettaz@gmail.com dicators studied were not significantly associated with meeting or not meeting the proAction criteria investigated in this study. Meeting the proAction lameness prevalence parameter was associated with an increased profitability margin per cow over replacement cost by $\$ 236$ compared with farms that did not. These results suggest that associations are present between meeting the lameness prevalence benchmark of the Animal Care proAction Initiative and freestall farms' productivity and profitability. Overall, meeting the animal-based criteria evaluated in this study was not detrimental to freestall farms' productivity and profitability.

Key words: animal welfare assessment, farm productivity, farm profitability, cow comfort

\section{INTRODUCTION}

Good animal welfare has always been an important preoccupation for dairy producers because good welfare practices can promote animal health and comfort (McInerney, 1998; De Grassi, 2001). However, over the last decades, public and consumer interest in this subject has greatly increased, leading to legislation and voluntary animal welfare standards being implemented. In addition, animal welfare assessment programs have been developed to monitor whether farms comply with these standards (Webster, 2012; Logue and Mayne, 2014). On-farm animal welfare assessments need to incorporate animal-based indicators, in addition to the typical resources-, records-, and management-based ones, to capture an accurate picture of the situation on a farm because animal welfare is multidimensional and has many different components (Rushen and de Passillé, 2009; Webster, 2012).

In North America, the US dairy industry has implemented the Farmers Assuring Responsible Management (FARM) program to monitor on-farm conditions of the animals and ensure that minimum standards are met (National Milk Producers Federation, 2016). In Canada, the Dairy Farmers of Canada association (DFC) 
has created a Code of Practice to establish standards of care for dairy animals (DFC-NFACC, 2009). Since the Canadian Code of Practice was implemented, a new producer-driven mandatory on-farm audit called the proAction Initiative has also been created. Over time, the complete assessment will cover areas including milk quality, food safety, livestock traceability, biosecurity, environment, and animal care (DFC-PLC, 2015). The Animal Care portion of the proAction program aims to measure the care, comfort, and well-being of dairy cattle on Canadian dairy farms to determine the extent to which the Canadian Code of Practice is being followed. In short, the proAction Animal Care assessment includes 20 main questions using 3 types of measures: animal-, management-, and resource/input-based, for a total of approximately 35 criteria evaluated (DFCPLC, 2015). For each measure, a benchmark has been set to discriminate between farms that meet or do not meet the criterion (DFC-PLC, 2015). Farms that will not meet the benchmarks will have to take corrective actions to remediate the problems. The Animal Care portion of proAction Initiative is a very recent audit that is currently being tested on-farm. Therefore, the benchmark limits currently in use represent the excellence targets for the farms. A ranking system using multi-level targets and based on comparison with peers will be created once a first set of assessment has been completed (Beauchamp, 2016).

Generally, following an on-farm assessment, recommendations are formulated to help dairy producers improve the situation on their farms. In some cases, the recommendations formulated to increase the animals' well-being require financial investments to be followed. For example, if producers are required to modify their housing system, the changes needed may be very expensive. In contrast, changes to the management may be less costly and even improve financial efficiency. In the dairy industry, as in many other industries, financial investments are easier to commit to when a financial gain is expected in return. Economic principles can play an important role to improve farm animal welfare (Christensen et al., 2012). Therefore, it is important to understand the links between meeting animal welfare standards and the farms' productivity and profitability. This information could help convince dairy producers to financially invest in the improvement of their animals' welfare, even if the cost may be elevated.

Currently, little scientific information is available on the associations between freestall farms' productivity and profitability and the farms' compliance with animal welfare standards. We evaluated the potential economic effects of meeting or not meeting several criteria from the new proAction Animal Care Initiative assessment. The farms' productivity and profitability were deter- mined based on milk production, milk quality, reproduction, animal longevity, and economic margins calculated over replacement cost. We also determined the extent to which meeting one aspect of proAction was related to meeting another aspect. This study focused on the animal-based criteria of the welfare assessment, which represent only a portion of the entire Animal Care portion of the proAction Initiative.

\section{MATERIALS AND METHODS}

The institutional animal care committees and research ethics boards of the University of Guelph (Guelph, Ontario, Canada, AUP \#10R110), Université Laval (Québec, Québec, Canada, CPAUL \#2010127), and University of Calgary (Calgary, Alberta, Canada, ACC \#SHC10R-07) approved all procedures.

\section{Herd and Animal Selection}

Canadian freestall dairy farms, 110 with milking parlors and 20 with automatic milking systems (AMS), were enrolled in this part of a larger cow comfort study from the 3 highest milk producing provinces of Canada; Alberta $(\mathrm{n}=51)$, Ontario $(\mathrm{n}=50)$, and Québec $(\mathrm{n}=$ 29; Vasseur et al., 2015). Characteristics of the farms are shown in Table 1. Participation in the study was on a voluntary basis and the initial contact was made through a mailed letter (Alberta and Ontario) or a phone call by the farm's DHIA advisor (Québec). To be eligible to participate, the herds needed to have a minimum of 40 Holstein dairy cows in lactation, not provide outdoor access to their lactating animals for more than $2 \mathrm{~h} / \mathrm{d}$, and having used their current housing system for at least 1 yr. For farms using a milking parlor, farms also needed to milk twice a day and be enrolled in their regional DHIA programs (CanWest DHI, Alberta and Ontario; Valacta Inc., Québec). Other selection criteria were based on the cows' longevity, in terms of percentage of cows in third or higher lactation and replacement rate, to capture farms with low, medium, and high longevity level based on provincial averages, and mean milk production $\geq 7,000 \mathrm{~kg}$ per cow per year (Vasseur et al., 2015). In Alberta, the farms also needed to participate in the Alberta Hoof Health Project to be enrolled in this study (Solano et al., 2015). The selection process for the farms visited was not truly random because of the different entrance criteria for the cow comfort study. However, the final sample of farms enrolled was representative of the Canadian dairy industry based on the average number of cows, average corrected yearly milk production, and general characteristics of the farms (AAFC, 2016; PLQ, 2016). 
Table 1. Characteristics of 110 dairy farms with milking parlors and 20 with automatic milking systems (AMS) in Alberta, Ontario, and Québec, Canada

\begin{tabular}{|c|c|c|c|c|c|c|c|c|}
\hline \multirow[b]{2}{*}{ Item } & \multicolumn{4}{|c|}{ Parlor farms } & \multicolumn{4}{|c|}{ AMS farms } \\
\hline & $\mathrm{n}$ & Mean & $\mathrm{SD}$ & Range & $\mathrm{n}$ & Mean & $\mathrm{SD}$ & Range \\
\hline$\overline{\text { No. of milking cows }}{ }^{1}$ & 110 & 156 & 92 & $48-505$ & 20 & 103 & 65 & $50-273$ \\
\hline Corrected milk production/yr, $\mathrm{kg}$ & 110 & 9,468 & 966 & $7,088-11,747$ & 19 & 9,477 & 1,020 & $7,366-11,599$ \\
\hline $\mathrm{SCC} / \mathrm{yr}(\times 1,000)$ & 109 & 215 & 70 & $77-370$ & 20 & 249 & 82 & $122-468$ \\
\hline Age at first calving, month & 110 & 26 & 1.4 & $21.6-30.5$ & 20 & 26 & 50 & $23.5-29.4$ \\
\hline DIM at first breeding & 107 & 79 & 13 & $60-126$ & 20 & 80 & 18 & $55-123$ \\
\hline Culling rate, ${ }^{2} \%$ & 110 & 36 & 8 & $15-54$ & 20 & 34 & 9 & $8-49$ \\
\hline$\%$ of cows in $3+$ lactation, $\%$ & 110 & 37 & 7 & $21-59$ & 20 & 37 & 9 & $23-57$ \\
\hline Margin per cow ${ }^{3} \$ / y r$ & 110 & 6,107 & 733 & $4,441-8,030$ & 19 & 6,220 & 891 & $4,253-8,525$ \\
\hline Margin per kg of quota, ${ }^{3} \$ / \mathrm{yr}$ & 110 & 5,843 & 222 & $5,283-6,500$ & 19 & 5,953 & 249 & $5,281-6,483$ \\
\hline
\end{tabular}

${ }^{1}$ Significant difference between parlor and AMS farms $(P \leq 0.05)$.

${ }^{2}$ Culling for reasons other than sold for milk production.

${ }^{3}$ Calculated on replacement costs.

On each farm, 40 focal cows were selected for data collection. The sample size of 40 cows per farm was based on a calculation to obtain a reliable lying time estimate, the primary target measure for the cow comfort assessment study (Vasseur et al., 2012). The cows were selected to be between 10 and 120 DIM and the selection reflected the proportion of primiparous and multiparous cows in lactation within the herd, when possible. If a farm did not have 40 milking cows between 10 and 120 DIM, the selection criterion was extended beyond 120 DIM until 40 cows were selected.

\section{Data Collection and Handling}

Fifteen observers were trained to collect all the animal- and resources-based measures using strict standard scoring protocols, which included both written descriptions and pictures, to ensure high repeatability between all observers (Vasseur et al., 2013; Nash et al., 2016). The majority of the scoring protocols used in this study were the precursors of the protocols used for proAction evaluation methods (DFC-PLC, 2015; Vasseur et al., 2015). The training of the observers has been previously described in Gibbons et al. (2012). Intra- and inter-observer repeatability was tested at different points during the data collection, and high levels of agreement were achieved (Gibbons et al., 2012; Vasseur et al., 2013). Each farm was visited by a pair of trained observers. The farm visits were conducted between January 2011 and April 2012.

In this study, our focus was on the animal-based measures; lesions, dirtiness, BCS, and lameness. In addition, we included one resource-based measure, stocking density, because it is an objective measure that had been recorded during the on-farm assessment and is often used to assess animal comfort in freestall farms.
Hock and knee lesions were scored using 4-level scorings systems $(0=$ no swelling or hair loss; $1=$ bald area/ swelling $<1 \mathrm{~cm} ; 2=$ lesion on bald area/swelling 1-2.5 $\mathrm{cm} ; 3=$ may have bald area/lesion and swelling $>2.5$ $\mathrm{cm})$, and neck lesions were scored using a 3-level scoring system $(0=$ no swelling/some broken hair; $1=$ no swelling/bald area visible; $2=$ broken skin or scab or swelling/may have a bald area), previously reported by Gibbons et al. (2012). For each focal cow, the aim was to evaluate all legs. However, for some animals only one front $(2 \%)$ or one back leg $(15 \%)$ could be evaluated. A cow was considered as having a lesion if at least one leg had a lesion score of 2 or more. Cows with neck score of 2 were considered as having a neck lesion. Dirtiness of the cows' leg, flank, and udder were scored using 4-level scoring systems $(0=$ contamination of fresh splashes of manure for $<50 \%$ of the area; $1=$ contamination of fresh splashes of manure for $>50 \%$ of the area; $2=$ contamination of dried caked and fresh manure for $>50 \%$ of the area; $3=$ contamination of entire area with dried caked manure; DFC-PLC, 2015; Bouffard et al., 2017). For each focal cow, only the lower right leg and right flank were scored for dirtiness. A cow was considered as dirty if she scored a level 2 or more. The BCS was scored using a simplified flowchart with scores ranging from $<2$ to 5 (Vasseur et al., 2013). The main objective of this flowchart was to detect the animals considered too thin, with $\mathrm{BCS} \leq 2$. Lameness prevalence on the farms was calculated based on the locomotion scoring of the 40 focal cows. Individual video recordings were taken for each focal animal walking and used to locomotion score each animal later using a simplified version of a validated numerical rating score (Chapinal et al., 2009; Ito et al., 2010). Locomotion scoring was done by observing the cows walking (at least 4 strides) while exiting the milking parlor or walking in the feeding alley 
(AMS) and recording the presence or absence of a limp, defined as the animal being reluctant to bear weight on at least 1 limb (Solano et al., 2015; Westin et al., 2016). Stocking density of housing pen was calculated using the number of cows in the pen divided by the number of usable stalls for the animals.

For each animal-based measure of the proAction Initiative, a benchmark has been set to discriminate between farms that meet and farms that do not meet each specific proAction criterion (DFC-PLC, 2015). The benchmarks for the proAction criteria included in the current study are presented in Table 2. These benchmarks have been set by a committee of the proAction Initiative and represent the excellence target limits for the farms. The entire Animal Care proAction assessment contains approximately 35 criteria grouped under 20 questions, but most of them were not measured during the on-farm comfort assessment and, therefore, were not included in the current study. The current study focused on the animal-based criteria.

Productivity indicators for each farm were based on the data collected by the regional DHIA programs during the 12 mo before the farm visits. The productivity indicators were the 12 -mo averages for yearly $4 \%$ fat- and $3.3 \%$ protein-corrected milk production $(\mathrm{kg})$, yearly SCC, calving interval (d), number of inseminations per cow per year, culling rate (\%), and percentage of cows in third lactation or higher. For the purpose of this study, a cow was considered as culled if she left the production herd for any reason other than being sold to another farm for milk production purposes. The farms' overall profitability was assessed using yearly margins per cow and per kilogram of production quota calculated over replacement costs. The profitability margins were calculated for each farm based on a 5-yr average (2010 to 2015 ) prices for milk solids $(\$ 9.67 / \mathrm{kg}$ of fat; $\$ 8.89 / \mathrm{kg}$ of proteins; $\$ 1.75 / \mathrm{kg}$ of other solids), market- ing cost ( $\$ 0.14 / \mathrm{kg}$ of milk solids), transportation cost $(\$ 2.559 / \mathrm{hL})$, heifer raising cost $(\$ 3,395 /$ animal $)$, cull cows' meat price $(\$ 795 / \mathrm{cow})$, and dead cows' removal cost $(\$ 60 /$ cow $)$. The same prices for milk, milk solids, and other costs were used to calculate the margins for all farms across the country. The price of an animal sold for dairy purpose was considered to be equal to the raising cost for a heifer. The margins were calculated over the replacements costs, and therefore, the margins presented in this study do not include costs such as feed or veterinary services.

\section{Statistical Analyses}

The data were analyzed using Stata 13 statistical software (StataCorp LP, College Station, TX). Descriptive statistics were generated separately for milking parlor and AMS farms to describe the characteristics of the farms included in this study. The agreement within a farm on meeting or not meeting the diverse proAction criteria evaluated was calculated by adding the number of farms that either met or did not meet the pair of criteria evaluated, divided by the total number of farms.

Univariable linear regression statistics were conducted to examined the relationships between the proAction results and the farms' characteristics, productivity, and profitability outcomes, for all farms together. Multivariable linear regression models were used to analyze the associations between meeting or not meeting a variety of individual proAction criteria and the following farm profitability indicators: average yearly fat- and proteincorrected milk production $(\mathrm{kg}$; corrected at $4 \%$ of fat and $3.3 \%$ of true protein), average yearly SCC, average calving interval $(\mathrm{d})$, average number of insemination per cow per year, culling rate $(\%)$, percentage of cows in third lactation or greater, yearly margin per cow over replacement costs, and yearly margin per kilogram

Table 2. Benchmarks of the proAction animal- and resource-based criteria included in this study and the number and percentage of freestall farms using milking parlors and automatic milking systems (AMS) that met the specific proAction criterion in Alberta, Ontario, and Québec, Canada

\begin{tabular}{|c|c|c|c|c|c|c|c|}
\hline proAction criterion & To meet proAction & \multicolumn{2}{|c|}{ Parlor farms } & \multicolumn{2}{|c|}{ AMS farms } & \multicolumn{2}{|c|}{ Total farms } \\
\hline Hock lesions $^{1}$ & $<10 \%$ of cows with lesion & 12 & 11 & 6 & 30 & 18 & 14 \\
\hline Neck lesions ${ }^{1}$ & $<10 \%$ of cows with lesion & 82 & 75 & 10 & 50 & 92 & 71 \\
\hline Flank dirtiness & $<20 \%$ of cows classified dirty & 103 & 94 & 20 & 100 & 123 & 95 \\
\hline Udder dirtiness & $<20 \%$ of cows classified dirty & 110 & 100 & 20 & 100 & 130 & 100 \\
\hline Lameness prevalence $^{2}$ & $<10 \%$ of obviously lame cows & 19 & 17 & 1 & 5 & 20 & 16 \\
\hline Stocking density & $\leq 120 \%$ & 103 & 94 & 19 & 95 & 122 & 94 \\
\hline
\end{tabular}

${ }^{1}$ Significant difference between farm types $(P \leq 0.05)$.

${ }^{2}$ Lameness prevalence missing for 1 AMS farm. 
Table 3. Percentage of farms where agreement that either met or did not meet both criteria of each pair of proAction criteria for 130 freestall farms in Alberta, Ontario, and Québec, Canada

$\%$ of farms with agreement ${ }^{1}$

\begin{tabular}{|c|c|c|c|c|c|c|c|c|}
\hline proAction criterion & $\begin{array}{l}\text { Hock } \\
\text { lesions }\end{array}$ & $\begin{array}{l}\text { Knee } \\
\text { lesions }\end{array}$ & $\begin{array}{l}\text { Neck } \\
\text { lesions }\end{array}$ & $\begin{array}{c}\text { Flank } \\
\text { dirtiness }\end{array}$ & $\begin{array}{c}\text { Udder } \\
\text { dirtiness }\end{array}$ & $\begin{array}{c}\text { Leg } \\
\text { dirtiness }\end{array}$ & BCS & $\begin{array}{l}\text { Lameness } \\
\text { prevalence }\end{array}$ \\
\hline Hock lesions & - & - & - & - & - & - & - & - \\
\hline Flank dirtiness & 18 & 29 & 69 & - & - & - & - & - \\
\hline Udder dirtiness & 14 & 29 & 71 & 95 & - & - & - & - \\
\hline Leg dirtiness & 44 & 38 & 62 & 71 & 69 & - & - & - \\
\hline Stocking density & 17 & 29 & 65 & 89 & 94 & 67 & 89 & 19 \\
\hline
\end{tabular}

${ }^{1}$ The percentage of agreement was calculated by adding the number of farms that either met or did not meet both proAction parameters divided by the total number of farms.

of quota over replacement costs. The farms' characteristics tested in the models were type of milking system (parlor or AMS), number of milking cows, percentage of primiparous cows in the milking herd, average milk production genetic index (CDN, 2007), average SCC genetic rating (CDN, 2007), age at first calving, and average DIM at first breeding. Genetic index for production and SCC were calculated by the Canadian Dairy Network using the Canadian Test Day Model. For any covariate, an initial cut-off value of $P<0.2$ in the univariable analysis was used as a prerequisite to be included in a multivariable model. A backward manual selection model building strategy was used to remove all nonsignificant terms in the models. The significance level was set at $\alpha=0.05$ for a variable to be retained in the final models. Partial F-tests and Akaike and Bayesian information criteria were used to assess the effect of removing categorical variables from models. Regardless of their statistical significance, confounding variables were retained in the models. Confounding variables were identified based on the causal diagram and if their removal resulted in a change of $20 \%$ or greater on the other significant variable coefficients. Two-way interactions between the proAction criteria and the additional covariates were tested based on biological plausibility and kept in the model if statistically significant. The referent for all proAction criteria was that farms did not meet the specific criterion.

For each linear model, the assumption of linearity was assessed visually based on the distribution of the residuals against the continuous predictors included in the model. If nonlinear, the variable was either modeled as a quadratic relationship, if appropriate, based on visual assessment of locally weighed regression curves (Lowess curves), or categorized. Collinearity between predictors was tested using Pearson or Spearman correlations or variance inflation factor. If 2 variables were found to be highly correlated (rho $\geq|0.8|$ ), only the variable with a higher level of interest to the study was used in the final model. Homoscedasticity and normality of the residuals were assessed visually using the distribution of the standardized residuals against the predicted values of the outcomes and the normal quantile plots, respectively. Outliers and influential observations were identified using visual assessment of standardized residuals, leverage, Cook's distance, and DFITS.

\section{RESULTS}

\section{Characteristics of Farms Enrolled}

The characteristics of the farms enrolled are shown in Table 1. Freestall farms with milking parlors had a significantly greater number of milking cows than AMS farms (Table 1). Table 2 shows the percentage of farms of each farm type that met each proAction criterion included in this study. Significant differences were found between parlor and AMS farms in the percentage of farms that met the proAction criteria for hock and neck lesions (Table 2). The agreement within a farm on meeting or not the various pairs of proAction criteria is presented in Table 3 . Two main clusters of criteria were found: one cluster included dirtiness, BCS, neck lesions, and stocking density, and the second cluster included leg lesions and lameness prevalence. High agreement were found especially between flank and udder dirtiness, flank dirtiness and BCS, udder dirtiness and BCS, flank dirtiness and stocking density, and udder dirtiness and stocking density (Table 3). The minimum number of criteria included in this study met by the farms was 3 , on a potential total of 9 , and this occurred only on 3 of the 130 farms. The maximum number of criteria met by a farm was 8 and this was achieved on 6 farms. 


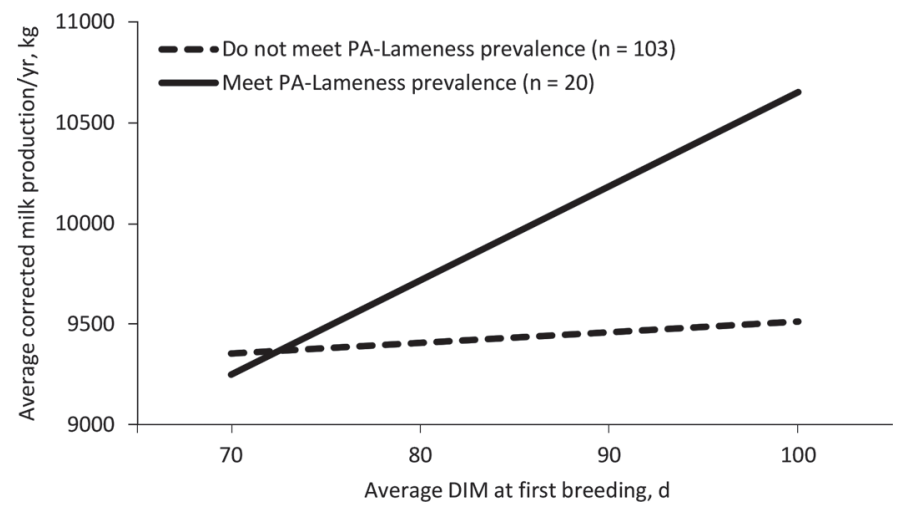

Figure 1. Effect of the interaction between average age at first breeding (d) and meeting or not meeting the proAction (PA) criterion for lameness prevalence on the average fat- and protein-corrected milk production per year $(\mathrm{kg})$ in 123 freestall farms in Alberta, Ontario, and Québec, Canada.

Overall, $65 \%$ of farms met between 5 and 6 criteria out of 9 .

\section{Milk Production and Milk Quality}

In the multivariate analysis, meeting or not meeting the proAction lameness prevalence criterion significantly interacted with DIM at first breeding for its association with average corrected milk production per year (Table 4 ). The increase in average yearly corrected milk production (365 d) with increasing average DIM at first breeding was more pronounced on farms that met the proAction lameness prevalence parameter compared with farms that did not (Figure 1). A higher average milk production genetic index was also significantly associated with a higher yearly average corrected milk production (Table 4). Yearly average SCC was not significantly associated with individual proAction parameters.

\section{Cow Reproduction}

In the univariate analysis, average calving interval was significantly and negatively associated with meeting the proAction criterion for hock lesions $(\beta=-12$; $95 \% \mathrm{CI}=-22$ to $-1 ; P=0.031)$ and positively associated with the stocking density criterion $(\beta=21 ; 95 \%$ $\mathrm{CI}=6$ to $36 ; P=0.007)$. At the multivariable analysis level, none of the proAction parameter significantly influenced the average calving interval or the average number of breeding per cow per year.

\section{Cow Culling and Longevity}

None of the proAction criteria included in the current study were significantly associated with culling rate, at the univariable or the multivariable analysis level. In contrast, the percentage of cows in third or higher lactation in the herd was positively associated with the proAction parameter for hock lesions in the univariable analysis with a higher percentage of cow in third or greater lactation in herd that met the criterion ( $\beta=4 ; 95 \% \mathrm{CI}=0.1$ to $7 ; P=0.047)$. However, at the multivariable analysis level, none of the criteria evaluated remained significant in the model.

\section{Overall Farm Profitability}

In the multivariate analysis, meeting or not meeting the proAction parameter for lameness prevalence was a confounder of the positive associations between margin per cow and the average milk production genetic index, and average DIM at first breeding and the negative association with average age at first calving (Table 5). The economical margin per kilogram of quota based on replacement cost was not significantly associated with individual proAction parameters.

Table 4. Multivariable linear regression models investigating the effects of meeting proAction parameters on the average corrected milk production per year $(\mathrm{kg})$ on 123 freestall farms in Alberta, Ontario, and Québec, Canada

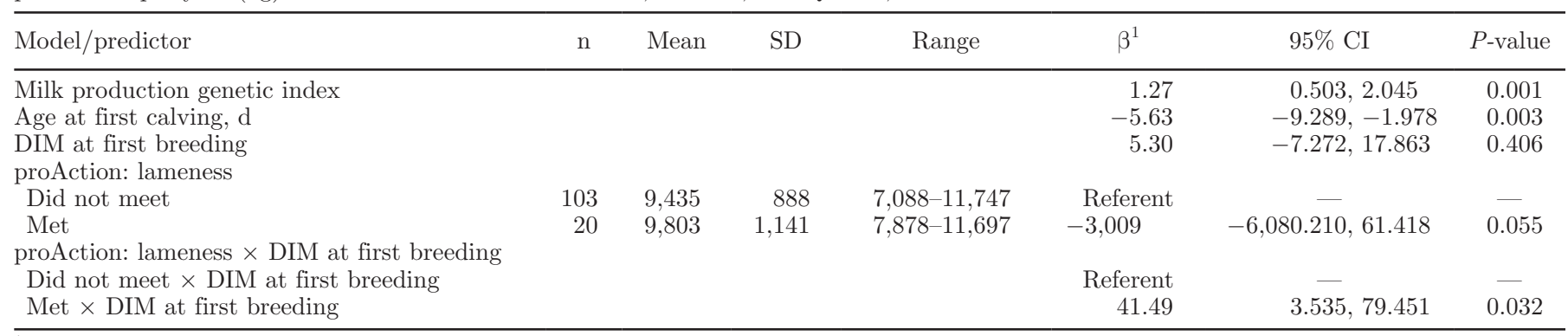

${ }^{1}$ Coefficient. 
Table 5. Multivariable linear regression model investigating the effects of meeting proAction parameters on the farms' yearly margin over replacement costs per cow on 123 freestall farms in Alberta, Ontario, and Québec, Canada

\begin{tabular}{lcccccc}
\hline Model/predictor & $\mathrm{n}$ & Mean & $\mathrm{SD}$ & Range & $\beta^{1}$ & $95 \%$ CI \\
\hline Milk production genetic index & & & & & 0.97 & $0.356,1.579$ \\
Age at first calving, d & & & & -4.42 & $-7.319,-1.526$ \\
DIM at first breeding & & & & & 0.002 \\
proAction: lameness & 103 & 6,076 & 716 & $4,254-8,526$ & Referent & 0.003 \\
Did not meet & 20 & 6,379 & 869 & $5,043-8,030$ & 235.80 & $-87.538,559.130$ \\
Met & & & & -19.865 \\
\hline
\end{tabular}

${ }^{1}$ Coefficient.

\section{DISCUSSION}

The focus of the current study was to evaluate the associations between the simulated results for the animalbased criteria of the proAction Animal Care assessment and freestall farm productivity and profitability. The majority of the proAction components tested were animal-based indicators, the stocking density criterion being the only other criterion tested. The complete proAction Animal Care assessment is composed of a much greater number of management- and resource-based criteria. The results are limited to the criteria evaluated and cannot be extrapolated to the other criteria included in proAction Animal Care assessment. Eight of the 9 animal-based criteria included in the proAction assessment were tested here. Meeting or not meeting the individual criteria of the proAction Animal Care assessment tested in this study was mainly associated with some indicators of farm performance in terms of milk production and economic margin per cow over replacement costs. None of the farms included in this study either failed or met all the criteria evaluated, and the majority of farms met 5 or 6 criteria of the 9 evaluated. Some of the criteria were met by the great majority or very few farms. This may have greatly influenced our ability to detect significant associations with the farms' productivity indicators in terms of reproduction and longevity. Our results show that farms that currently meet the animal-based proAction criteria are not doing any worse economically than farms that do not, suggesting that meeting these standards does not impose an economic burden on the Canadian dairy industry as a whole. However, it is difficult at this point to conclude about the extent to which changes made to meet a specific proAction criterion at the individual farm level will increase or decrease the farm profitability.

The proAction Animal Care criteria are clustered into 2 groups. The farms' results for the lameness criterion were likely to be the same as their results for the leg lesions criteria and the farms' results for the BCS criterion were also likely to be the same as their results for the dirtiness, neck lesions, and stocking density criteria. These clusters of animal-based measures were not surprising as previous research has shown similar associations, often linked to stall dimensions or management (Fulwider et al., 2007; Kielland et al., 2009; Westin et al., 2016; Adams et al., 2017). Associations between cows' BCS and lying time have also been previously established, which could partly explain the cluster found between BCS and animal dirtiness (Bewley et al., 2010; Westin et al., 2016). Although the focus was upon animal-based components of the proAction Animal Care assessment, the criterion for stocking density was included in this study because previous onfarm assessment have shown that it can significantly affect cow behavior and productivity (Fregonesi et al., 2007; King et al., 2016). It was, however, impossible to test the associations between stocking density and the indicators of farm productivity in the current study due to a lack of variance as $94 \%$ of farms had met the criterion.

Meeting some of the individual components of proAction assessment scheme was associated with measures of farm productivity and profitability. The negative effects of lameness on farm productivity and profitability is well documented with reduced milk production and reproductive success and estimated cost ranging from $\$ 100$ to $\$ 500$ depending on the disease and its severity (Willshire and Bell, 2009; Huxley, 2013; Charfeddine and Pérez-Cabal, 2017). In the current study, meeting or not the criteria for lameness prevalence was associated with yearly corrected milk production but this relationship was moderated by average DIM at first breeding, which is a management decision usually based on voluntary waiting period and service rate. Still, meeting the criterion for lameness prevalence was associated with higher milk production for the majority of farms. The profitability margin per cow, over replacement costs, was also improved by $\$ 236$ in farms that met the proAction lameness prevalence criterion.

In this study, farm productivity in terms of reproduction was assessed through the average calving interval and average number of breeding per cow per year. The average culling rate and percentage of cows in their third lactation or greater were used as longevity indicators of farm productivity and profitability. None of the 
individual proAction criteria evaluated in this study were significantly associated with these productivity indicators at the multivariable analysis level, likely because of the lack of variance in the number of farms that either met or did not meet the criteria.

The animal welfare standards and on-farm assessments that have been recently introduced in North America and Europe are primarily intended to reassure consumers and food retailers that farm animals are being treated humanely. Their primary purpose is not to improve farm productivity and profitability. Demonstrating the existence of positive associations between animal well-being and farm productivity and profitability would provide a great incentive to stimulate dairy producers to invest toward improvements of the comfort and welfare of their animals. In this study, the criteria for udder and flank dirtiness, BCS, and stocking density were also met by more than $90 \%$ of the farms visited. In contrast, the criteria for hock lesions and lameness prevalence were met by less than $20 \%$ of the farms. These results were not very surprising as previous on-farm assessments have revealed the low levels of cow dirtiness and high levels of leg injuries and lameness achieved in freestall farms (Lombard et al., 2010; Barrientos et al., 2013; Watters et al., 2013).

It is important to remember that the benchmarks used for each criterion included in this study are the current proAction Animal Care benchmarks to distinguish the excellent farms. Although the objective of the current study was to test the associations between achieving these benchmarks and farm productivity and profitability, future research should evaluate the association between animal welfare indicators measured on a continuous scale and farm productivity and profitability. This would likely facilitate finding benchmarks that would be optimal for both animal welfare and farm profitability. In addition, the complete animal care assessment includes additional criteria to the ones included in this study and these may be linked with farm productivity and profitability. Overall, meeting the animal-based proAction Animal Care criteria assessed in the current study was positive for the dairy farmers because it did not seem to impose any economic burden on them and promotes a positive image of the dairy industry.

\section{CONCLUSIONS}

None of the 130 freestall farms included in this study met all 9 proAction Animal Care criteria evaluated. The hock lesions and lameness prevalence criteria were met by the least number of farms and the udder dirtiness criterion was met by all farms. Meeting the lameness prevalence criterion of the proAction assessment for animal welfare was associated with indicators of farm productivity and profitability. In general, these results suggest that meeting these components of the animal welfare assessment is unlikely to impose any economic burden on the Canadian dairy industry as a whole and could be financially beneficial for individual farms, depending on the changes required to achieve these benchmarks. Future research should focus on understanding the minimal animal welfare level to achieve to avoid detrimental effects to farm productivity and profitability, and the financial improvements associated with increasing welfare on a continuous scale.

\section{ACKNOWLEDGMENTS}

This research was funded by Agriculture and AgriFood Canada (AAFC; Ottawa, Ontario, Canada) and Dairy Farmers of Canada (Ottawa, Ontario, Canada) as part of the Dairy Science Cluster initiative, the Fonds Québécois de la Recherche sur la Nature et les Technologies (FQRNT; Québec City, Québec, Canada)- Novalait (Quebec, Quebec, Canada)-Ministère de l'Agriculture, des Pêcheries et de l'Alimentation du Québec (MAPAQ; Québec, Québec, Canada), and by Alberta Milk (Edmonton, Alberta, Canada). The authors also thank the students and research coordinators who organized and collected the data: Jenny Gibbons and Gemma Charlton (AAFC, Agassiz, British Columbia, Canada), Clémence Nash and Jessica Zaffino (University of Guelph, Guelph, Ontario, Canada), Véronique Bouffard and François Bécotte (Laval University, Québec City, Québec, Canada), and Laura Solano and Guiherme Bond (University of Calgary, Calgary, Alberta, Canada).

\section{REFERENCES}

AAFC (Agriculture and Agri-Food Canada). 2016. Statistics of the Canadian Dairy Information Center. Assessed Nov. 16, 2016. http://dairyinfo.gc.ca/index_f.php?s1=dff-fcil\&menupos=1.1.

Adams, A. E., J. E. Lombard, C. P. Fossler, I. N. Román-Muñiz, and C. A. Kopral. 2017. Associations between housing and management practices and the prevalence of lameness, hock lesions, and thin cows on US dairy operations. J. Dairy Sci. 100:2119-2136. https://doi.org/10.3168/jds.2016-11517.

Barrientos, A. K., N. Chapinal, D. M. Weary, E. Galo, and M. A. G. von Keyserlingk. 2013. Herd-level risk factors for hock injuries in freestall-housed dairy cows in the northeastern United States and California. J. Dairy Sci. 96:3758-3765. https://doi.org/10.3168/ jds.2012-6389.

Beauchamp, M. 2016. Évaluation des mesures axées sur les animaux. Pages 16-18 in Le Producteur de Lait québécois. October issue. Longueuil, Québec, Canada.

Bewley, J. M., R. E. Boyce, J. Hockin, K. Munksgaard, S. D. Eicher, M. E. Einstein, and M. M. Schutz. 2010. Influence of milk yield, stage of lactation, and body condition on dairy cattle lying behaviour measured using an automated activity monitoring sensor. J. Dairy Res. 77:1-6. https://doi.org/10.1017/S0022029909990227. 
Bouffard, V., A. M. de Passillé, J. Rushen, E. Vasseur, C. G. R. Nash, D. B. Haley, and D. Pellerin. 2017. Effect of following recommendations for tiestall configuration on neck and leg lesions, lameness, cleanliness, and lying time in dairy cows. J. Dairy Sci. 100:29352943. https://doi.org/10.3168/jds.2016-11842.

CDN (Canadian Dairy Network). 2007. Genetic evaluation of dairy cattle in Canada. Accessed Aug. 22, 2017. https://www.cdn.ca/ document.php?id $=123$.

Chapinal, N., A. M. de Passillé, D. M. Weary, M. A. G. von Keyserlingk, and J. Rushen. 2009. Using gait score, walking speed, and lying behavior to detect hoof lesions in dairy cows. J. Dairy Sci. 92:4365-4374. https://doi.org/10.3168/jds.2009-2115.

Charfeddine, N., and M. A. Pérez-Cabal. 2017. Effect of claw disorders on milk production, fertility, and longevity, and their economic impact in Spanish Holstein cows. J. Dairy Sci. 100:653-665. https:// doi.org/10.3168/jds.2016-11434.

Christensen, T., A. Lawrence, M. Lund, A. Stott, and P. Sandoe. 2012. How can economists help to improve animal welfare? Anim. Welf. 21:1-10. https://doi.org/10.7120/096272812X13345905673449.

De Grassi, A. 2001. A look at bovine welfare-What's good, what's bad, and the lessons within. J. Am. Vet. Med. Assoc. 219:1369 1373. https://doi.org/10.2460/javma.2001.219.1369.

DFC-NFACC (Dairy Farmers of Canada and the National Farm Animal Care Council). 2009. Code of Practices for the Care and Handling of Dairy Cattle. Dairy Farmers of Canada, Ottawa, Ontario, Canada.

DFC-PLC (Dairy Farmers of Canada-Producteurs laitier du Canada). 2015. Farmer manual-Animal Care \& Livestock Traceability. Dairy Farmers of Canada, Ottawa, Ontario, Canada.

Fregonesi, J. A., C. B. Tucker, and D. M. Weary. 2007. Overstocking reduces lying time in dairy cows. J. Dairy Sci. 90:3349-3354. https://doi.org/10.3168/jds.2006-794.

Fulwider, W. K., T. Grandin, D. J. Garrick, T. E. Engle, W. D. Lamm, N. L. Dalsted, and B. E. Rollin. 2007. Influence of free-stall base on tarsal joint lesions and hygiene in dairy cows. J. Dairy Sci. 90:3559-3566. https://doi.org/10.3168/jds.2006-793.

Gibbons, J., E. Vasseur, J. Rushen, and A. M. de Passillé. 2012. A training programme to ensure high repeatability of injury scoring of dairy cows. Anim. Welf. 21:379-388. https://doi.org/10.7120/ 09627286.21.3.379.

Huxley, J. N. 2013. Impact of lameness and claw lesions in cows on health and production. Livest. Sci. 156:64-70. https://doi.org/10 .1016/j.livsci.2013.06.012.

Ito, K., M. A. G. von Keyserlingk, S. J. LeBlanc, and D. M. Weary. 2010. Lying behavior as an indicator of lameness in dairy cows. J. Dairy Sci. 93:3553-3560. https://doi.org/10.3168/jds.2009-2951.

Kielland, C., L. E. Ruud, A. J. Zanella, and O. Østeras. 2009. Prevalence and risk factors for skin lesions on leg of dairy cattle housed in freestalls in Norway. J. Dairy Sci. 92:5487-5496. https://doi .org/10.3168/jds.2009-2293.

King, M. T. M., E. A. Pajor, S. J. LeBlanc, and T. J. DeVries. 2016. Associations of herd-level housing, management, and lameness prevalence with productivity and cow behavior in herds with automated milking systems. J. Dairy Sci. 99:9069-9079. https://doi .org/10.3168/jds.2016-11329.

Logue, D. N., and C. S. Mayne. 2014. Welfare-positive management and nutrition for the dairy herd: A European perspective. Vet. J. 199:31-38. https://doi.org/10.1016/j.tvjl.2013.10.027.
Lombard, J. E., C. B. Tucker, M. A. G. von Keyserlingk, C. A. Kopral, and D. M. Weary. 2010. Associations between cow hygiene, hock injuries, and free stall usage on US dairy farms. J. Dairy Sci. 93:4668-4676. https://doi.org/10.3168/jds.2010-3225.

McInerney, J. 1998. Animal welfare: Ethics, economics and productivity. Cattle Pract. 6:89-90.

Nash, C. G. R., D. F. Kelton, T. J. DeVries, E. Vasseur, J. Coe, J. C. Zaffino Heyerhoff, V. Bouffard, D. Pellerin, J. Rushen, A. M. de Passillé, and D. B. Haley. 2016. Prevalence of and risk factors for hock and knee injuries on dairy cows in tiestall housing in Canada. J. Dairy Sci. 99:6494-6506. https://doi.org/10.3168/jds .2015-10676.

National Milk Producers Federation. 2016. National dairy FARM (Farmers Assuring Responsible Management) program 2017 animal care reference manual. Assessed Dec. 12, 2016. http://www nationaldairyfarm.com/.

PLQ (Producteurs de lait du Québec). 2016. L'évolution de la production laitière Québécoise 2015. Page 38 in Le Producteur de Lait québécois. June issue. Longueuil, Québec, Canada.

Rushen, J., and A. M. de Passillé. 2009. The scientific basis of animal welfare indicators. In The Assessment and Management of Risks for the Welfare of Production Animals. Food Safety Assurance and Veterinary Public Health. Vol. 5. F. J. M. Smulders and B. Algers, ed. Wageningen Academic Press, Wageningen, the Netherlands.

Solano, L., H. W. Barkema, E. A. Pajor, S. Mason, S. J. LeBlanc, J. C. Zaffino Heyerhoff, C. G. R. Nash, D. B. Haley, E. Vasseur, D. Pellerin, J. Rushen, A. M. de Passillé, and K. Orsel. 2015. Prevalence of lameness and associated risk factors in Canadian HolsteinFriesian cows housed in freestall barns. J. Dairy Sci. 98:6978-6991. https://doi.org/10.3168/jds.2015-9652.

Vasseur, E., J. Gibbons, J. Rushen, and A. M. de Passillé. 2013. Development and implementation of a training program to ensure high repeatability of body condition scoring of dairy cows. J. Dairy Sci 96:4725-4737. https://doi.org/10.3168/jds.2012-6359.

Vasseur, E., J. Gibbons, J. Rushen, D. Pellerin, E. Pajor, D. Lefebvre, and A. M. de Passillé. 2015. An assessment tool to help producers improve cow comfort on their farms. J. Dairy Sci. 98:698-708. https://doi.org/10.3168/jds.2014-8224.

Vasseur, E., J. Rushen, D. B. Haley, and A. M. de Passillé. 2012. Sampling cows to assess lying time for on farm animal welfare assessment. J. Dairy Sci. 95:4968-4977. https://doi.org/10.3168/ jds.2011-5176.

Watters, M. E. A., K. M. A. Meijer, H. W. Barkema, K. E. Leslie, M. A. G. von Keyserlingk, and T. J. DeVries. 2013. Associations of herd- and cow-level factors, cow lying behavior, and risk of elevated somatic cell count in free-stall housed lactating dairy cows. Prev. Vet. Med. 111:245-255. https://doi.org/10.1016/j.prevetmed .2013.05.015.

Webster, J. 2012. Critical control points in the delivery of improved animal welfare. Anim. Welf. 21:117-123. https://doi.org/10.7120/ $096272812 X 13345905673962$.

Westin, R., A. Vaughan, A. M. de Passillé, T. J. DeVries, E. A. Pajor, D. Pellerin, J. M. Siegford, A. Witaifi, E. Vasseur, and J. Rushen. 2016. Cow- and farm-level risk factors for lameness on dairy farms with automated milking systems. J. Dairy Sci. 99:3732-3743. https://doi.org/10.3168/jds.2015-10414.

Willshire, J. A., and N. J. Bell. 2009. An economic review of cattle lameness. Cattle Pract. 17:136-141. 